\title{
The Political Economy of Global Mobility
}

Alex Taek-Gwang Lee

\begin{abstract}
In this essay, I will discuss the political economy of global mobility through an analysis of the relationship between nation-states and globalization. Today's aspect of global mobility lies with the logistics of people and goods within and beyond the national governmentality. These logistics flows construct the supply chain locally and globally with infrastructures, people, goods, and information. What must be stressed here is the new role of nation-states in the rise of globalizing logistics. Following the neoliberal model, each nation-state takes on a crucial role in creating markets. In this situation, the dialectics of tourists and the multitude is noteworthy. While the multitude does not belong to the nation-states any longer, tourists as consumers are entrapped to the category of the labor force, i.e., the commodification of labor power. If people want to move from one nation-state to another nation-state, they have to choose whether to be a labor commodity or a consumer. The working class is the moveable population and portable labor force, yet they are legally obliged to stay within a specific territory. It is not labor force but money or a commodity that is permitted to travel around. Although a commodity can be exchanged with money, they are not the same. The monetary circulation brings out the capitalist mobility of production, whereas a commodity completes its final function when it is consumed. In other words, consumption means the withdrawal of a commodity from the circulation. When a commodity is consumed, its function is done, its form finally annihilates, and then money moves from one territory to another in search of different commodities. Global mobility is fueled by the monetary flow, the financial flux in a global scope; nevertheless, its real excursion cannot be withdrawn from the political economy of the Urstaat. I contend that this double-binding relationship is the political deadlock of the Empire and the nation-states.
\end{abstract}

Keywords: tourist, multitude, nation-states, Empire

(C) 2021 Alex Taek-Gwang Lee

https://www.kritike.org/journal/special issue 2021/a lee april2021.pdf

ISSN 1908-7330 


\section{THE POLITICAL ECONOMY}

\section{The Rise of Deadly Logistics}

$\mathrm{M}$

oving people and goods is the material foundation of global capitalism. The high mobility of developed transportation, such as air travel, has accelerated globalization. Whoever finds the reality of the terrestrial integration should consider the effects of global mobility on each local identity. The primitive accumulations of capitalism would be impossible if there is no geographical difference. It all began with trade but ended up with imperialism and colonialization. Karl Marx was one of the European intellectuals in the $19^{\text {th }}$ century who were preoccupied with this early form of globalization. Observing the first stage of global capitalism, Marx pointed out that "the discovery of gold and silver in America, the extirpation, enslavement, and entombment in mines of the indigenous population of that continent, the beginnings of the conquest and plunder of India, and the conversion of Africa into a preserve for the commercial hunting of blackskins are all things which characterize the dawn of the era of capitalist production." 1 Following this early stage of accumulation, the globe turns into a battlefield of the European empires' commercial war.

As Marx described, imperial expansion is nothing more than the creation of the European bourgeoisie after its own image. The imperialism did not bring forth a unified world but instead belied colonial subsumption and racialized differentiation. The legacy of the capitalist expansion in the $20^{\text {th }}$ century ended up with two destructive wars and the rise of the nation-states as its aftermath. The postwar nation-states are the political venue of decolonization and, simultaneously, a battleground between socialism and capitalism. However, after the collapse of the socialist bloc in the 1990s, the nation-states come to play a different role from its political origins. The nation-state as the material realization of a nation, i.e., an imagined community, changes to the proponent of globalization. The tension between nationalization and globalization here seems to have lessened but has been left undissolved. From the ruins of the empire, this globalist project replaces colonialism, which has more often been called neoliberalism since the 1980s. Despite many criticisms, the so-called neoliberal champions believe that the global system, the economic replacement of old empire, is a regulated world in which capital and goods move freely according to the principle of supply and demand, producing prosperity for all.

In this sense, today's aspect of global mobility coincides with the logistics of people and goods within and beyond the national governmentality. These flows of the logistics construct the supply chain

${ }^{1}$ Karl Marx, Capital: A Critique of Political Economy, vol. 1, trans. by Ben Fawkes (London: Penguin, 1990), 915.

(C) 2021 Alex Taek-Gwang Lee

https://www.kritike.org/journal/special issue 2021/a lee april2021.pdf

ISSN 1908-7330

(c) $)$ BY-NC-ND 
locally and globally with infrastructures, people, goods, and further information. In her book on global logistics, Deborah Cowen argues:

Casually referred to by those in the industry as a "pipeline," logistics space contrasts powerfully with the territoriality of the national state. Today, the supply chain is understood to be both vital and vulnerable and so in urgent need of protection. This networked space surfaces over and over again as the object of supply chain security, rendering its trademark cartography. The corporate supply chain has a history in the military and colonial supply line. It is no accident that the supply chain of contemporary capitalism resonates so clearly with the supply line of the colonial frontier. ${ }^{2}$

What must be stressed here is the new role of the nation-states in the rise of globalizing logistics. In the neoliberal model, each nation-state takes a crucial role in creating markets. The neoliberal government of the state is the dramatic transformation of the state-machine, i.e., the Leviathan, whose body is made up of all the bodies of its citizens. When Thomas Hobbes used this metaphor for describing the unity of commonwealth between the sovereign and people, he presupposed people's authorization of a common representative acting in their names. According to Hobbes, the state is identical with one person as the representative of the sovereign authority, but not the representation of itself. The state must be the incorporation of each single constituent member, for the unity of the "representer," not "represented," can make the "person one." 3 This argument tacitly reveals the paradox of the state: the sovereign power as the one person has to exist before the representation of people and brings forth its capacity to act as one. In other words, the one person brought up by the united multitude in a common representative is also created by the sovereign.

\section{Leviathan as an Enterprise}

Indeed, it is the sovereign who decides which people can be included and excluded from the representation. The logic of the modern state operates as if the commonwealth squarely corresponds with the representation of all members. Still, the unity of the "representer" is already established before its representative embodiment. In this sense, the body of any democratic polity

2 Deborah Cowen, The Deadly Life of Logistics: Mapping Violence in Global Trade (Minneapolis: The University of Minnesota Press, 2014), 8-9.

${ }^{3}$ Thomas Hobbes, Leviathan (Indianapolis: Hackett, 1994), 104.

(c) 2021 Alex Taek-Gwang Lee

https://www.kritike.org/journal/special issue 2021/a lee april2021.pdf

ISSN 1908-7330

(cc) BY-NC-ND 


\section{THE POLITICAL ECONOMY}

always already preserves the exceptional state of sovereignty. Therefore, neoliberal globalization does not abolish the hidden impetus behind a modern state but instead reinforces its capability to unite people as one by the exclusion of those who are not supposed to be included in the unity. This enhancement of the authority leads to the modification of the role of the nation-states in building up the global supply chain of commodities. With this novel role, the Leviathan turns out to be an enterprise to administrate economic policy and markets. There is no retreat of the state but the reassertion of the sovereignty as one person. The local governments of the nation-states universalize competition and create the market-oriented systems of action for individuals and business groups as well as institutions. The new task of regional administration fundamentally reshapes the utopian credo of a nation-state, i.e., the equality of all members within its communal boundary.

A nation-state is the material foundation of a nation. The imagined nation roots in the idea of the commonwealth, in particular, the republican ideal. Based on the republican constitution, the reign of the nation-state mostly aims to protect property but at the same time presupposes the absolute equality among the members of the nation. Two aspects of the nation-state are consolidated in the ideology of national prosperity. In the process of nation-building, the ideology comes along with the sovereign power to discipline the multitude to the abstractive idea of people. Michel Foucault pointed out the primitive violence in the birth of a nation, since the disciplinary power of the sovereignty, unlike Hobbes's presupposition, does not mean the end of wars but brings forth another war: the violent decision as to who is inclusive or exclusive within the border of a nation-state. ${ }^{4}$ The war within the state is a civil war, the return of bellum omnium contra omnes, the war of all against all. This theoretical model of the permanent struggling with each other explains the homeostasis of a nation-state. The imaginary ideal of a nation, which springs out from the transcendental idea of the universal right, i.e., the absolute equality of the national members, always already overdetermines the presence of people, the reality of the nation-state. According to Foucault,

The individual as such, in his relationship with others, is the bearer of this permanent possibility of the war of all against all. If there is in fact a war of all against all, it is first of all essentially because men are equal in the objects and ends they set their sights on, because they are

\footnotetext{
${ }^{4}$ Michel Foucault, The Punitive Society: Lectures at the Collège de France 1972-1973, trans. by Graham Burchell (London: Palgrave, 2015), 24.

(c) 2021 Alex Taek-Gwang Lee https://www.kritike.org/journal/special issue 2021/a lee april2021.pdf ISSN 1908-7330
}

(c) BY-NC-ND 
equivalent in the means they possess for obtaining what they seek. They are, as it were, substitutable for each other, and that is precisely why they seek to replace each other and, when something is offered to the desire of one, the other may always substitute himself for the first, wanting to take his place and appropriate what he desires. This substitutability, this convergence of desire characterizes this original competition. ${ }^{5}$

Foucault observes this principle of competition as "quasi-equality," i.e., a rationale for the "dimension of distrust." By this suspicion, each individual in the nation-state knows well that someone else may come to replace them. What must be stressed here is that this dynamic of competition is the most crucial feature founding the function of the sovereign. In my opinion, here, Foucault's insight into the state power reveals how the lack of trust brings forth the war of all against all back into the inside of a nationstate. Without any solution to the civil war, the nation-state would not be sustainable, and then surmounting the mistrust and suspending the competition is the only solution necessary for the due procedure of the nation-building. The political resolution to the problems is to create the glorious one person, i.e., "one of these perpetual combatants" winning over their rivals "by something like an additional power." 6 The power of glory is, of course, the system of signs, the instrumental function of nationalism to bring together those individuals who are on the point of a civil war within a nation-state. For this reason, the eruption of civil wars means the terminal state of the dissolution of the sovereign, the disappearance of the triumphant one.

It seems to me that this Hobbesian fantasy is the foundation of nationalism which aims to maintain the ideological rationale of a nation-state. However, the rise of neoliberal globalization threatens the ground of national integrity. Many arguments concerning this transformation of a nation-state have mainly focused on the neoliberal shift of governmentality from a social welfare system to a market economy. By this move, the role of government in the markets seems necessarily retreated. From the perspective of the political economy, it is undeniable that the global interconnection facilitates more dynamic interactions. The buzzwords in the age of the neoliberal globalization are the stateless corporation, the round-the-clock global financial market, the edged competition under flexible capital and the rule of a single price, and the globally connected information society. However, one

${ }^{5}$ Ibid., 25-26.

${ }^{6}$ Ibid., 26.

(c) 2021 Alex Taek-Gwang Lee https://www.kritike.org/journal/special issue 2021/a lee april2021.pdf ISSN 1908-7330 


\section{THE POLITICAL ECONOMY}

of the essential features of this transformation is the ascendence of global urbanism. The upsurge of the global cities imposes significant alterations on the raison d'état of a nation-state.

\section{The Urban "Supermodernity"}

There has been a familiar argument revolving around the relationship between globalization and the nation-states, which points out the relative weakening of the nation-states, focusing on the diminishing national economy in the phase of globalization. Jan Nederveen Pieterse argues, "globalization can mean the reinforcement of both supranational and subnational regionalism."7 The theory of postmodernism seeks to carve out the politics of hybridity in the dialectics of globalization and localization. More interestingly, the cultural entanglements do not mean that the nationstate as such comes to be multicultural but instead is divided by global urbanization. No doubt, the rapid improvement of mobility through technology and connectivity more and more precipitates the emergence of the global cities and universalization of its urbanism. My argument is that the rise of the cosmopolitan megalopolis within the nation-states is the foundation of global mobility. Globalization signifies the disintegration of national and local borders, and the main cities in each nation-state come to function as an intensively interconnected hub of global logistics.

In this way, the global cities no longer belong to the national space but stand detached and isolated from it. The international metropolis simply serves as the totality of "non-places." As Marc Augé points out, "if a place can be defined as relational, historical, and concerned with identity, then a space which cannot be defined as relational, or historical, or concerned with identity will be a non-place." 8 In other words, the non-places are the areas without identity such as "the mobile cabins called means of transport (aircraft, trains, and road vehicles), the airports and railway stations, hotel chains, leisure parks, large retail outlets, and, finally, the complex skein of cable and wireless networks." 9 "Supermodernity," which exceeds Baudelaire's conceptualization of modernity, produces the non-places: "transit points and temporary abodes." However, Augé's concept of supermodernity, the condition of the non-places, needs to be clarified further. He seems to assume the divide between modernity and supermodernity. The latter is the excessive modernity which has three features such as

\footnotetext{
${ }^{7}$ Jan Nederveen Pieterse, Globalization and Culture: Global Mélange (London: Rowman and Littlefield, 2009), 71.

${ }^{8}$ Marc Augé, Non-Places: Introduction to an Anthropology of Supermodernity, trans. by John Howe (London: Verso, 1995), 77-78.

${ }^{9}$ Ibid., 74.

(C) 2021 Alex Taek-Gwang Lee

https://www.kritike.org/journal/special issue 2021/a lee april2021.pdf

ISSN 1908-7330
}

(c) $)$ BY-NC-ND 
"overabundance of events, spatial overabundance, the individualization of references." 10

Yet, the "excessive" factors are not employed only for the explanation of supermodernity. The flourishing of the non-places does not only apply to supermodernity, since modernity always already precipitates the overwhelming flow of moving people and goods. Marx and Engels' description of capitalism lies with the fact that "all that is solid melts into air," the lightness and weightlessness of modernity. In 1848, they already pointed out that the global extension of the bourgeois market gives rise to the modern liquidity; in their words, "the need of a constantly expanding market for its products chases the bourgeoisie over the whole surface of the globe." 11 In this sense, colonialism is the early phase of global capitalism and has still been embodied in modernity's cultural logic. Therefore, I contend that there is no fundamental distinction between modernity and supermodernity, but rather many continuities inherited from the early globalization. What makes a difference between modernity and supermodernity is nonetheless the advancement of transportation and communication technology. In particular, the progress of aviation technology and information technology, e.g., the Internet, have rapidly sped up global mobility. For this reason, the unprecedented growth of international logistics, prompted by new technology, should be regarded as the material foundation of the non-places.

The non-places are, in this sense, nothing more than the fluidity of the urban spatio-temporality and the nodal points of global connectivity. This liquid modality of global urbanism, which removes history and identity from the geographical locations, is the de facto bedrock of supermodernity. In Baudelaire's sense, the anonymous crowd is the protagonist at the modern city, but the non-places of the global megalopolis have no leading character. On the surface, the cultural hybridity comes to exist in the segregated urban space within a nation-state, yet, the deeper layer of the spatial experiences is essentially homogenous, i.e., the single modality of urban consumerism is dominant in such cosmopolitan multiculturalism. Whatever it takes at the local place, everything has to be modified by the global standard's refined demands. Urbanity turns to be the daily norms of life embedded in globalization. The early figure of radical Enlightenment such as "noble savage" becomes replaced with the typical image of the metropolitan elite. The urban cosmopolitanism is a mixed breed but not equally enjoyed by all those living in the nation-state. This inequality stands against the political doctrine of nationalism that promises the members of a nation-state the absolute equality and brings the unification of sovereignty and people into a

${ }^{10}$ Ibid., 40.

${ }^{11}$ Karl Marx and Frederick Engels, The Communist Manifesto (New York: International Publishers, 1948), 12. 


\section{THE POLITICAL ECONOMY}

crisis. Due to this split between people and their representatives, democracy does not work out, and then the political catastrophe of a nation-state ends up with the rise of populism.

What must be stressed here is that the urban-centrism brings forth the new modes of existence. The city dwellers are not only those who populate in urban areas but also the consumers of city commerce. The metropolitan consumerism gains its ultimate form in tourism, the commodification of leisure. As Dean MacCannell argues in his classic analysis of a tourist, the highly commercialized space of global cities is "a stage set, a tourist setting, or simply, a set depending on how purposefully worked up for tourists the display is." 12 This appearance of a tourist, in contrast with an adventurer, is often accused by intellectuals as shallow and superficial in that the tourist experience is not authentic and always mystified, further disguises itself as the revelation of the truth. Daniel Boorstin's description of a tourist as the consumer of a pseudo-adventure is one of such orthodox examples to criticize the fabricated real life of a tourist. ${ }^{13}$ According to him, a tourist, whose risks are insurable, does not venture to encounter any native in an unknown place but keep on the mirror-image of themselves wherever they visit. However, the tourist setting is "not merely copies or replicas of real-life situations but copies that are presented as disclosing more about the real thing than the real thing itself discloses." 14 What Boorstin does not recognize in his criticism of a tourist is that tourism, per se, is the failed resistance to the metropolitan elitism, which ultimately gains success in confirming it.

Meanwhile, MacCannell accounts the tourist as an ontological condition of a modern man. He claims that tourism is an attempt to overturn alienation, yet a failure to end up with the reaffirmation of their alienation. Due to this alienated state of existence, a tourist is always blamed for their superficial understanding of other people and places, i.e., their ignorance of objectivity in the way things ought to be seen. In MacCannell's sense, global tourism is the expansion of modernity and the alienating obscurity of the distinction between work and leisure. He argues:

In industrial society, work is broken down into "occupations" and it provides livelihood and status on the individual level. Modern society transforms this same work into a positive and negative aesthetic of

\footnotetext{
12 Dean MacCannell, The Tourist: A New Theory of the Leisure Class (Berkeley: The University of California Press, 2013), 102.

${ }^{13}$ Daniel J. Boorstin, The Image: A Guide to Pseudo-Events in America (New York: Vintage, 1987), 91.

${ }^{14}$ MacCannell, The Tourist, 102.

(c) 2021 Alex Taek-Gwang Lee

https://www.kritike.org/journal/special issue 2021/a lee april2021.pdf

ISSN 1908-7330
}

(cc) BY-NC-ND 
production ... The work displays about to be discussed, and the work displays in general, unify economics and aesthetics and they begin to replace industrial concerns for social class and status with the modern concern for "lifestyle." They dramatize the enormous differentiation of the modern work force and, at the same time, reintegrate all classes of workers, from stock brokers to sewer cleaners, in a single system of representations. They obscure the distinction industrial society makes between human and machine labor by displaying the two as inextricably linked in unified design as occurs, for example, in tours of assembly lines. ${ }^{15}$

The point of his argument is that the reality of the work resists the symbolic structure of tourism. The work is what is repressed, i.e., the unconscious layer, in the dramatization and representation of tourism. However spectacular it is, the presence of workforces let the sightseers have the straight experience of society's real side, even though a worker and a tourist are divided. MacCannell's tourist theory elucidates the structure of tourism and the constancy of the tourist as a modern man. Nevertheless, his semiotic analysis of a tourist attracted by sightseeing underestimates global tourism's political economy, which precipitates the spatial separation of the tourist areas from any domestic territory.

\section{Tourists and the Multitude}

To push MacCannell's idea further, Hiroki Azuma's philosophy of a tourist deserves attention here. For Azuma, a tourist is a philosophical theme for understanding the dialectical relationship between Empire and nationstates and can be defined as a "postal multitude." 16 He takes the notion of the multitude from Antonio Negri and Michael Hardt's discussion of the Empire and Jacques Derrida's concept of the postal. In Empire, Negri and Hardt argue that "the creative forces of the multitude that sustain the Empire are also capable of autonomously constructing a counter-Empire, an alternative political organization of global flows and exchanges."17 Azuma critically considers this conceptualization of the multitude and attempts to turn its political weaknesses into strengths. For him, the most fundamental problem of the concept resides in the way in which there is no possible political agenda

\footnotetext{
${ }^{15}$ Ibid., 62.

${ }^{16}$ Hiroki Azuma, The Philosophy of the Tourist 観光客の哲学 (Tokyo: Genron, 2017), 157.

17 Antonio Negri and Michael Hardt, Empire (Cambridge, Massachusetts: Harvard University Press, 2000), 15.
} 


\section{THE POLITICAL ECONOMY}

in Negri and Hardt's theory of the multitude. ${ }^{18}$ According to him, the only rationale of the multitude is the self-organization of global networks. Furthermore, its political motivations and orientations are very ambiguous because they merely suggest that "biopower and communism, cooperation and revolution remain together, in love, simplicity, and also innocence." 19 All those virtues, i.e., love, simplicity, innocence, are ethical rather than political, and Azuma argues that Negri and Hardt's optimistic vision of the multitude as such ironically reveals the political powerlessness of their concept.

On the contrary, Azuma finds out the possibility of a tourist in the political failure of the multitude. For him, the problem of the multitude comes from the fact that they cannot have the grand narratives to unite themselves under the same political doctrine. The rejection of the orthodox political thoughts is their ontological essence, nevertheless, the very absence of the traditional utopianism, or the skepticism of realpolitik, is paradoxically the most fragile point of the multitude. Indeed, Azuma's concept of a tourist shares the same condition of global capitalism with Negri and Hardt's concept of the multitude; however, his assumption is that a tourist is nothing less than the reification of "misdelivery" (誤配), the incarnation of the failed communication containing the many performative possibilities. A tourist comes to exist where the multitude fails to gain its unification. The misdelivery, the possibility of the delivery of goods to a wrong party, is a tourist's condition that brings out the unpredictable touristic situation. What they want to see is occasionally informed against what they experience. In this way, their travel always pertains to otherness that they cannot predict and must be supplemented by posteriority. There is no actual alliance, but this repetitive post-configuration of supplements sustains the possibility of the association. This idea is similar to MacCannell's affirmation of tourists as those who participate in others' lives. A tourist's encounter with the others at the places they visit is the modern man's existential condition. Both MacCannell and Azuma regard a tourist as the ontological form of high modernity and the generic mode of existence in global capitalism. In this sense, a tourist could be called the embodiment of cosmopolitanism and the European Enlightenment's global realization.

In my view, however, the multitude is not a mere mirror image of the tourists but rather the primordial substance of those who suffer from global capitalism. The concept is spun off from Spinoza's monism and aims to explain ontological multiplicity. Therefore, it is not wrong to say that tourists are much the same as the multitude, in that the multitude has various modes of existence. Negri and Hardt clearly describe the "postmodern" prototype of

${ }^{18}$ Azuma, Philosophy of the Tourist, 146.

${ }^{19}$ Negri and Hardt, Empire, 413.

(c) 2021 Alex Taek-Gwang Lee

https://www.kritike.org/journal/special issue 2021/a lee april2021.pdf

ISSN 1908-7330

(cc) BY-NC-ND 
the multitude as the militant. They argue that "as the figure of the people dissolves, the militant is the one who best expresses the life of the multitude: the agent of biopolitical production and resistance against the Empire." 20 They take the examples of the militant, mainly those communist and liberatory combatants, antifascist intellectuals, the republicans during the Spanish civil war and the resistance movements in the Second World War, and the anticolonial and anti-imperialist guerrilla warriors. Here, Negri and Hardt suggest the concept of the multitude as counter-Hobbesian; the multitude does not belong to the nation-states any longer. This idea corresponds to Marx and Engel's grave-digger dialectics: the capitalist mode of production inevitably produces its destroyers, the proletariat. Negri and Hardt insist that the dialectical movement finally ends up with the ossification of the socialist states. Negri and Hardt intend to criticize the stateform of socialism with the concept of the multitude. The militant is those figures that have already come to exist through the previous resistances within and without the nation-states.

Unlike Negri and Hardt's understanding of the multitude, still, I would say that the multitude discloses the paradox of political economy within Empire; the labor force of global capitalism has to stay within the domestic assembly lines, even though they work for the global companies, and the only way that the local workers can cross the borders of the nationstates is to be a tourist. Any worker, as far as they are regarded as labor force, cannot travel across the national boundaries. Of course, a tourist is not a militant. Azuma's concept of a tourist sheds light on this ontological distinction between two modes of existence. I would like to go beyond his argument. My assumption is that what makes the labor force as a particular tourist is the legal right of travel. A tourist must be identified legitimately as the specific people of any nation-state, while a militant resists the authority's national identification. If you need a lawful permission to visit any country, that means that you are always subsumed to the nation-states. This fact proves that the nation-states are not the outside of Empire but the parts of its assemblages. Nationalism, the absent cause of the nation-states, consists of the partial drives within the Empire, but does not ensure the dissolution of the state-form. In this sense, the ontological modes of the militant, not tourists, are the more salient incarnation of the multitude. Ironically, the militant is neither people nor tourists, yet the third modes of existence between the nation-states and the Empire. They stay in the national territories but are politically dislocated by their global engagement from within. I think that this political disjoint is a critical gap between a tourist and a militant; the

${ }^{20}$ Ibid., 411.

(c) 2021 Alex Taek-Gwang Lee https://www.kritike.org/journal/special issue 2021/a lee april2021.pdf ISSN 1908-7330 


\section{THE POLITICAL ECONOMY}

tourist is never displaced with the nation-states, while the militant struggles to be dismembered with the national body.

\section{The Militant Against Urstaat}

In this sense, the militant should be understood as those who resist the authority to vouch for their rights of travel and identify themselves with those who have no such documents, i.e., sans papiers. As the primordial substance of the militant, the ontological state of the multitude is close to refugees rather than tourists. According to Negri and Hardt, the multitude is "social flesh" that is not a body but "a flesh that is common, living substance":

The flesh of the multitude is pure potential, an unformed life force, and in this sense an element of social being, aimed constantly at the fullness of life. From this ontological perspective, the flesh of the multitude is an elemental power that continuously expands social being, producing in excess of every traditional politicaleconomic measure of value [...]. From the perspective of political order and control, then, the elemental flesh of the multitude is maddeningly elusive, since it cannot be entirely corralled into the hierarchical organs of a political body. ${ }^{21}$

The flesh of the multitude is the deformation of the Leviathan's body, the expansion of social being against the unification of people and the person one and the excessive production of values against the political economy. These expansions and productions are not quantitative but qualitative, and then the multitude is "an irreducible multiplicity; the singular social differences that constitute the multitude must always be expressed and can never be flattened into sameness, unity, identity, or indifference," not multiple fragments but "singularities that act in common." 22 What is noteworthy here is that the multitude is the counter-concept of the Urstaat, the primordial violence of the state-form, which is "the eternal model of everything the State wants to be and desires." ${ }^{23}$ It is the State that expresses and constitutes the objective movements of production. People are the

${ }^{21}$ Antonio Negri and Michael Hardt, Multitude: War and Democracy in the Age of Empire (London: Penguin, 2004), 192.

22 Ibid., 105.

${ }^{23}$ Gilles Deleuze and Félix Guattari, Anti-Oedipus: Capitalism and Schizophrenia, trans. by Robert Hurley, Mark Seem, and Helen R. Lane (Minneapolis: University of Minnesota Press, 1983), 237.

(C) 2021 Alex Taek-Gwang Lee https://www.kritike.org/journal/special issue 2021/a lee april2021.pdf

ISSN 1908-7330

(c) $)$ BY-NC-ND 
captured force of production in the state-form and, in this sense, another side of the multitude. The multitude is nothing less than those who have never been represented by the nation-states, even though living inside it, the void of the Urstaat, which repetitively creates the transcendental outside of a specific state-form from within. Unlike MacCannell's structuralist presupposition, in this sense, the modern man's generic condition is not a tourist but a refugee.

For now, Azuma's question of the multitude still remains. The multitude as the dissolution of people could be regarded as the ontological resistance to the Urstaat, although not automatically becoming militant. Their ontological state is not the only condition of "militant-becoming." Azuma's concept of a tourist tries to solve this problem by endorsing small-world and scale-free mathematical models. Small-world networks are typified by local clustering and shortcut ties that reduce the path length between clusters, while scale-free networks take an asymmetrical distribution. Therefore, small-world networks serve as equally contingent connections, but scale-free networks function as unequally skewed distribution. According to Azuma, the nation-states could be called the small-world network, and the Empire could be regarded as the scale-free network. ${ }^{24}$ The doctrine of the nationstates is the equality of all national members within their small-worlds, whereas the principle of Empire imposes its unequal dissemination of the scale-free networks on the small-worlds. Based on this presupposition, he argues that a tourist is a "political" existence to recuperate the contingency of "misdelivery" in-between the small-world network and the scale-free network.

Nevertheless, it seems to me that the Empire is not simply the mathematical model but the actualization of global capitalism. Even though the Empire does the work of the scale-free network, the fundamental inequality of the world order is ascribable to capitalism on a global scale. Empire as a scale-free network would enhance the hierarchical disparity, but the politico-economic unevenness among the nation-states is not the consequence of the mathematical law. Darwin's theory of evolution can be adopted to explain that the fittest survive in nature. Yet, its application for the justification of social meritocracy falls into the trap of ruling class ideology. "Social Darwinism" shows the typical fallacy of such pseudoscientific exercises. Above all, it is not self-evident that a tourist is a political subject. The common mode of tourists is a consumer in high capitalism. They have to buy the travel commodities, in other words, and thus become a consumer if they want to encounter the enigmatic others. Travel has the allure of the most popular commodities, and the development of mass transportation has

${ }^{24}$ Azuma, Philosophy of the Tourist, 192.

(c) 2021 Alex Taek-Gwang Lee https://www.kritike.org/journal/special issue 2021/a lee april2021.pdf ISSN 1908-7330 


\section{THE POLITICAL ECONOMY}

enhanced the travel industry's competitiveness. During the last decades, air tickets have become the most decomposable commodity with the advent of the low-budget tourist. As a member of the nation-states and at the same time a cosmopolitan consumer of Empire, a tourist has to fulfill the requirements of global capitalism, i.e., money and the rights of travel.

When tourists lose the rights of travel and money, they are forced to become refugees. This moment is when the repressed reality of global capitalism returns. In this sense, tourists are another mode of refugees and vice versa. In fact, the ambiguous status of a tourist is not political in itself; "misdelivery" is not the ontological state only adequate to a tourist but communication in general. As a consumer, tourists want to extend their places to wherever they visit. A tourist's illusion would break down as they encounter the reality of capitalism and are dissociated with their habitual perception of others. What is necessary for this to happen is méconnaissance, the misrecognition of the ego, i.e., the very function of a mirror-image. A tourist's ego always looks for their mirror-image in others, but this expectation is occasionally staggered by the real experiences. If a tourist comes across this strangeness by chance, they are no longer who they were. This overdetermined misunderstanding, i.e., each cause is necessary to bring forth an effect in the situation of méconnaissance, is the existential condition of a tourist and leads them to the subjectivation of the multitude. In this sense, the militant is not the opposite figure of the tourist but more like their qualitatively transformed subject, the monstrous metamorphosis of a consumer. Therefore, what is crucial in a tourist's political reversion is not the mechanism of "misdelivery" as such but their militant subjectivation.

\section{Conclusion}

Marx pointed out that production creates a consumer: "production not only supplies a material for the need, but it also supplies a need for the material." 25 A tourist as a consumer is also entrapped in the category of the labor force, i.e., the commodification of labor power. If anybody wants to move from one nation-state to another nation-state, they have to choose whether to be a labor commodity or a consumer. Mobility is the key feature of capitalism. The working class is the moveable population and portable labor force, yet they are legally obliged to stay within a specific territory. It is not labor force but money and a commodity that are permitted to travel around. Although a commodity can be exchanged with money, they are not the same. Marx argued that "the function of money ... is to remain in

${ }^{25}$ Karl Marx, Grundrisse: Foundations of the Critique of Political Economy, trans. by Martin Nicolaus (London: Penguin, 1993), 92.

(C) 2021 Alex Taek-Gwang Lee

https://www.kritike.org/journal/special issue 2021/a lee april2021.pdf

ISSN 1908-7330

(c) $)$ BY-NC-ND 
circulation as its vehicle, to resume its circular course always anew like a perpetuum mobile." 26 The monetary circulation brings out the capitalist mobility of production, whereas a commodity completes its final function when it is consumed. In other words, consumption means the withdrawal of a commodity from the circulation. When a commodity is consumed, its function is done, its form finally annihilates, and then money moves from one territory to another in search of different commodities. For this reason, the labor force, so far as it is a commodity retracted from its circulation, has no mobility. Global mobility is fueled by monetary flow, the financial flux in a global scope; nevertheless, its real excursion cannot be withdrawn from the political economy of the Urstaat. I contend that this double-binding relationship is the political deadlock of the Empire and the nation-states.

School of Global Communication, Kyung Hee University, South Korea

\section{References}

Augé, Marc, Non-Places: Introduction to an Anthropology of Supermodernity, trans. by John Howe (London: Verso, 1995).

Azuma, Hiroki, The Philosophy of the Tourist 観光客の哲学 (Tokyo: Genron, 2017).

Boorstin, Daniel J., The Image: A Guide to Pseudo-Events in America (New York: Vintage, 1987).

Cowen, Deborah, The Deadly Life of Logistics: Mapping Violence in Global Trade (Minneapolis: The University of Minnesota Press, 2014).

Deleuze, Gilles, and Felix Guattari, Anti-Oedipus: Capitalism and Schizophrenia, trans. by Robert Hurley, Mark Seem, and Helen R. Lane (Minneapolis: University of Minnesota Press, 1983).

Foucault, Michel, The Punitive Society: Lectures at the College de France 19721973, trans. by Graham Burchell (London: Palgrave, 2015).

Hobbes, Thomas, Leviathan (Indianapolis: Hackett, 1994).

Marx, Karl, Capital: A Critique of Political Economy, vol. 1, trans. by Ben Fawkes (London: Penguin, 1990).

Grundrisse: Foundations of the Critique of Political Economy, trans. by Martin Nicolaus (London: Penguin, 1993).

Marx, Karl, and Frederick Engels, The Communist Manifesto (New York: International Publishers, 1948).

MacCannell, Dean, The Tourist: A New Theory of the Leisure Class (Berkeley: The University of California Press, 2013).

26 Ibid., 202.

(c) 2021 Alex Taek-Gwang Lee

https://www.kritike.org/journal/special issue 2021/a lee april2021.pdf

ISSN 1908-7330

(cc) BY-NC-ND 


\section{THE POLITICAL ECONOMY}

Negri, Antonio, and Michael Hardt, Empire (Cambridge, Massachusetts: Harvard University Press, 2000). Multitude: War and Democracy in the Age of Empire (London: Penguin, 2004).

Pieterse, Jan Nederveen, Globalization and Culture: Global Mélange (London: Rowman and Littlefield, 2009). 